\title{
Willingness-to-pay Comparisons for Flats of Groundcover Plants in Plantable Containers: Consumers versus Commercial Buyers in Kentucky
}

\author{
Dewayne L. Ingram ${ }^{1,3}$ \\ Department of Horticulture, University of Kentucky, $\mathrm{N}-318 \mathrm{Ag}$ Science \\ Center, Lexington, KY 40546-0091
}

\author{
Timothy A. Woods ${ }^{1}$ and Wuyang $\mathrm{Hu}^{1}$ \\ Department of Agricultural Economics, University of Kentucky, 400 C.E. \\ Barnhart Building, Lexington, KY 40546-0276
}

\author{
Susmitha S. Nambuthiri ${ }^{2}$ \\ Department of Horticulture, University of Kentucky, N-318 Ag Science \\ Center, Lexington, KY 40546-0091
}

Additional index words. Ajuga reptans 'Bronze Beauty', Sedum kamtschaticum 'Variegatum', SoilWrap, Ellepot, plantable containers, conjoint analysis

\begin{abstract}
Increasing demand for groundcover plants and increasing consumer preference for more sustainable products encourage nursery crop producers and landscape management companies to assess efficiency and sustainable practices. Ajuga reptans 'Bronze Beauty' and Sedum kamtschaticum 'Variegatum' were grown in standard plastic containers or plantable containers (Ellepot and SoilWrap) and 12- or 18-count flats. These production alternatives were presented in personal surveys of commercial industry personnel and consumers to determine their willingness to pay for these attributes. A conjoint analysis revealed an affinity for both groups to purchase flats of groundcovers and preferred sedum over ajuga. Commercial buyers from larger companies were more likely to purchase plantable containers than those from smaller firms. Generally, flats of Ellepots were preferred over flats of SoilWraps and 18-count over 12-count flats by commercial buyers. Price had a negative impact on consumer willingness to pay. Consumers revealed no specific preference for the plantable containers, although preference for plastic containers declined with age and presence of children at home.
\end{abstract}

Groundcover plants are in demand for residential and commercial landscapes as a result of the aesthetic appeal of masses of these low-growing plants, low maintenance requirement, enhanced environmental impact by reducing storm water runoff velocity, and controlling weeds in landscapes (Klett and Wilson, 2009). Nambuthiri and Ingram (2014) reported that commonly marketed groundcover plants in Kentucky, 'Bronze Beauty' ajuga (Ajuga reptans), 'Herman's Pride' lamiastrum (Lamiastrum galeobdolon), 'Beacon Silver' lamium (Lamium maculatum), 'Immergrunchen' sedum (Sedum hybridum), 'Red Carpet Stonecrop' sedum (Sedum spurium), and 'Vera Jameson' sedum (Sedum telephium), could be grown to a marketable size from $3.8-\mathrm{cm}$ plugs in 8 weeks in Lexington, KY. Plant quality and growth rates for these plants were similar in

Received for publication 23 Oct. 2014. Accepted for publication $23 \mathrm{Jan} .2015$.

This research was funded in part by a Kentucky Specialty Crop Block Grant.

${ }^{1}$ Professor.

${ }^{2}$ Postdoctoral Scholar.

${ }^{3}$ To whom reprint requests should be addressed; e-mail dingram@uky.edu. two plantable containers (Ellepot and SoilWrap) and a standard plastic container and established well in the landscape. The plantable containers also required $20 \%$ less time to transplant into the landscape and reduced the requirement for plastic recycling or disposal. A study of the willingness of U.S. floral crop growers to adopt practices perceived to be more sustainable revealed that although growers had positive attitudes toward sustainable practices, their adoption was tempered by concerns of implementation and perceived risks (Hall et al., 2009).

Consumer perceptions of eco- or environmentally friendly products are diverse (Gladwin et al., 1995; Purser et al., 1995) but consumer demand for product stewardship or environmentally conscious products and business practices is increasing (Dennis et al., 2010; Rihn et al., 2011). Ottman (1998) reported that customers were most interested in already existing ordinary products compared with more green products as a result of price, past performance, or product ignorance or disbelief. On average, the 535 consumers surveyed in Texas, Michigan, Minnesota, and Indiana liked rice hull pots followed by straw containers compared with standard containers
(Hall et al., 2010). Approximately one-third of those surveyed were indifferent to container type. Yue et al. (2010) used auction data to determine that consumers representative of the U.S. population had a positive willingness to pay for floral crops in several different biodegradable containers compared with standard plastic containers. However, the degree of that willingness to pay varied with specific biodegradable container. Yue et al. (2011) found through an Internet survey that consumers in Indiana, Michigan, Minnesota, and Texas were interested in plants being locally grown and produced in more sustainable containers. Biodegradable and compostable containers were more desirable than recycled containers. This study also reported that sociodemographic characteristics of study participants affected their preference for plants. For example, individuals interested in purchasing organic food were most interested in organically produced plants. Another conjoint analysis of survey results revealed that U.S. and Canadian consumer intentions were most affected by plant type followed by origin of production and container type (Behe et al., 2013). A web-based study focused in Texas to determine consumer preference for attributes of container gardens revealed that the relative importance decreased from price $(71 \%)$ to amount of care information $(23 \%)$ to color harmony (6\%) (Mason et al., 2008). The participants' preferred price point was $\$ 24.99$ and desired care information and complementary color harmony. Khachatryan et al. (2014a) showed through a mixed-ordered probit model from an online survey that consumers were willing to pay a premium for non-plastic or plantable containers. Similar results were found from plant auction experiments conducted in the United States and Canada (Khachatryan et al., 2014b). A study that examined determinants of consumer expenditure shares for bedding plants specifically noted higher relative expenditures for younger, higher income, higher educated, white consumers who had lived longer in their current residence (Jin et al., 2013).

Two years of research determined that plantable containers were suitable for production of groundcover plants and their establishment in the Kentucky landscape (Nambuthiri and Ingram, 2014). The next step in this project was to determine the acceptance of two common groundcover plants grown in plastic and plantable containers by commercial installers and consumers shopping at an independent garden center. Traditionally, these buyer groups have quite different buying patterns. Commercial installers would be expected to purchase in bulk, look for volume discounts, and have a view toward providing an installation service, whereas garden center consumers would be more likely to be purchasing in smaller lots for home installation. A conjointtype survey was designed to determine their willingness to pay for alternative container technologies, plant type, and flat size.

Plantable characteristics of containers typically have inherent credence dimensions; the value contained in the product may not be 
immediately obvious to the buyer. The approach of conjoint analysis has been widely applied in cases in which there are credence attributes to elicit respondents' stated choice behavior (Carlsson et al., 2007; Hu et al., 2005; Johnston and Duke, 2007).

\section{Materials and Methods}

Ajuga reptans 'Bronze Beauty' and Sedum kamtschaticum 'Variegatum' plugs from 72-count flats $(\approx 1.5$-inch-diameter cells $)$ were supplied by Emerald Coast Growers (Pensacola, FL) and were transplanted into one of three test containers in 12- or 18-count flats on 17 June 2013 in Lexington, KY. Containers tested were standard 76-mm round plastic containers $\left(300 \mathrm{~cm}^{3}\right.$ volume), $90-\mathrm{mm}$ paper containers $\left(570 \mathrm{~cm}^{3}\right.$ volume Ellepot; Ellegaard A/S, Storstrømsvej 55, Denmark; supplied by The Blackmore Co., Belleville, MI), or $80-\mathrm{mm}$ bioplastic containers (SoilWrap; $330-\mathrm{cm}^{3}$ volume; Ball Horticultural Company, Chicago, IL). Each species was transplanted to 10 flats of each container type and flat size. Selection of test plants and containers was based on a 2-year study evaluating plant production and establishment criteria (Nambuthiri and Ingram, 2014). Plants were fertigated weekly or when the electrical conductivity of a pour-through extraction fell below $1.0 \mathrm{dS} \cdot \mathrm{M}^{-1}$ with $200 \mathrm{mg} \cdot \mathrm{L}^{-1}$ nitrogen solution from Peters Excel $(21 \mathrm{~N}-$ 2.2P-16.6K) (Everris, Dublin, $\mathrm{OH}$ ) and grown in a Quonset-style, white plastic-covered greenhouse with sidewalls and ends removed for ventilation. Plants were observed daily and hand-watered as required. Plants grown in these treatment containers and flat sizes were used as examples in the in-person survey of consumers and commercial nursery/landscape industry personnel to determine their willingness to pay for features of the treatments.

Two buyer populations (commercial buyers and consumers) were identified as potentially valuing alternative containers for groundcover plants. Separate surveys were developed to elicit willingness to pay (WTP) from these distinct buyer populations in Kentucky with a view toward comparing valuation of various attributes. The WTP evaluation would help determine marginal values these groups placed on containers that would be associated with various ecologically friendly packaging and lower time of installation. Point-of-survey information was provided in a poster that indicated relative installation times and other container benefits. These buyer populations traditionally approach groundcover purchases differently; commercial buyers inclined to buy in bulk and consumers were more inclined to buy smaller lots in retail settings. Two plant types were introduced as variables to increase the robustness of the marginal effects of container type and flat size. Different bundles of products and packaging size may be sold at different prices. Consumer WTP for each type of product (and each attribute associated) is expected to vary across individuals. The range of prices used in the conjoint experiment should be wide enough to cover the potential
WTP (Hanemann and Kanninen, 1999). Before the implementation of the survey, careful market evaluation and pre-testing with commercial garden centers were conducted to ensure both lower and higher end possible prices were included. A total of three price levels were used to maintain the balanced statistical property of the conjoint experiment while maintaining simplicity (Louviere et al., 2000). Several other studies adopted the same strategy (e.g., Hu et al., 2005). Table 1 lists the attributes as well as the levels within each attribute considered for the conjoint survey. Table 2 shows the specific information provided at the survey setting and displayed in front of the corresponding plants and containers. A sign also indicated the corresponding groundcover plant variety. Both 12- and 18-count options of each plant variety and container type were included in the display. Container characteristics were provided to each group surveyed: commercial buyers and consumers.

Given the number of attribute options considered for each product, a D-optimal fractional factorial design was applied and generated six profiles for each product. This design allows the main and first-order interaction effects not to be confounded (Louviere et al., 2000). Other studies have successfully used this type of design and generated reliable results (e.g., Lusk et al., 2008). Four choice sets were constructed based on these profiles with each choice set containing two alternatives resembling two profiles with respective price. A third "empty" alternative was added

Table 1. Groundcover conjoint attribute summary.

\begin{tabular}{lllll}
\hline Attribute & Container type & \multicolumn{1}{c}{ Groundcover } & \multicolumn{1}{c}{ Flat size } & \multicolumn{1}{c}{ Price } \\
\hline Levels & Ellepot & Ajuga reptans & 12-count flat & Commercial buyers: \\
& SoilWrap & 'Bronze Beauty' & 18-count flat & $\$ 15, \$ 20, \$ 25 /$ flat \\
& Standard Plastic & Sedum & & Home-based buyers: \\
& & kamtschaticum & & $\$ 35, \$ 45, \$ 50 /$ flat \\
& & 'Variegatum' & & \\
\hline
\end{tabular}

Table 2. Container characteristics communicated to commercial buyers and consumers in the willingnessto-pay experiment.

\begin{tabular}{|c|c|c|c|}
\hline Container type & Ellepot & SoilWrap & Standard plastic \\
\hline \multirow{5}{*}{$\begin{array}{l}\text { Stated } \\
\text { characteristics }\end{array}$} & Plantable container & Plantable container & Plastic container-not plantable \\
\hline & Material: paper & Material: paper & Material: plastic-blow mold \\
\hline & Container decomposes & Container decomposes & Container will not decompose \\
\hline & No waste or recycling & No waste or recycling & Plastic recycling or waste \\
\hline & $\begin{array}{l}\text { Transplanting } 20 \% \text { faster } \\
\text { than standard plastic } \\
\text { container }\end{array}$ & $\begin{array}{l}\text { Transplanting } 20 \% \text { faster } \\
\text { than standard plastic } \\
\text { container }\end{array}$ & $\begin{array}{l}\text { Transplanting requires } 20 \% \\
\text { more time than plantable } \\
\text { containers }\end{array}$ \\
\hline
\end{tabular}

Table 3. Sample choice task for a commercial buyer.

Please select your preference for $\boldsymbol{O N E}$ of the choices below (control one).

$\square$ \$20/flat, SoilWrap container, Sedum kamtschaticum 'Variegatum', 18-count flat

$\square$ \$15/flat, Ellepot container, Ajuga reptans 'Bronze Beauty', 12-count flat

$\square$ I would choose neither option

Table 4. Variables for commercial buyer demographic characteristics.

\begin{tabular}{lccccl}
\hline Variable & Mean & SE & Minimum & Maximum & Description \\
\hline Lower sales volume & 0.359 & 0.480 & 0 & 1 & $<\$ 250,000$ annual sales, dummy \\
Higher sales volume & 0.297 & 0.457 & 0 & 1 & $\$ 500,000+$ annual sales, dummy \\
Firm in city/suburban location & 0.536 & 0.499 & 0 & 1 & City/suburban location, dummy \\
Firm in rural location & 0.172 & 0.377 & 0 & 1 & Farm location/dummy \\
\hline
\end{tabular}


a raffle for a specimen plant. Table 5 displays the demographic characteristics of the consumers. The sample size is limited by the complexity of the experiment, but the distribution of demographics similarly follows the high levels of income, education, and age observed in national consumer studies on nursery products and landscaping projects surveys (Baldwin, 2013; Jin et al., 2013).

The economic framework for consumer decision-making with bundled attributes in a conjoint experiment follows. Suppose in the $t$-th choice situation, individual $i$ sees the $j$-th flower product. The product is represented by the attributes considered in this study and included in vector $\mathbf{X}_{\mathbf{i j}}$. The individual will indicate alternative $j$ as the preferred alternative only when the individual receives the highest amount of utility associated with alternative $j$ when compared with other alternatives offered in the same choice situation $t$. The indirect utility $\left(U_{i j t}\right)$ associated with alternative $j$ can be derived through Random Utility theory (McFadden, 1974):

$$
U_{i j t}=\mathbf{X}_{\mathrm{ijt}} \boldsymbol{\beta}+e_{j t}
$$

where $\boldsymbol{\beta}$ is a vector of the utility parameters associated with product attributes and $e_{j t}$ is an error term. Following McFadden (1974), the error term can be conveniently assumed to follow an iid maximum extreme value Type I distribution. Under this assumption, the choice probability of individual $i$ choosing alternative $j$ in the $t$-th choice set can be written into:

$$
P_{i j t}=\frac{\exp \left(\mathbf{X}_{\mathbf{i j t}} \boldsymbol{\beta}\right)}{\sum_{k=1}^{J} \exp \left(\mathbf{X}_{\mathbf{i k t}} \boldsymbol{\beta}\right)}
$$

Product attribute variables often do not function alone in terms of their impact to utility. The impacts from these attributes are often manifested through decision-makers' characteristic variables. As a result, the basic choice model in equation (2) can be augmented by including the interacted terms between respondent demographic variables and product attribute variables (Colombo et al., 2007). NLOGIT4.0 (Econometric Software Inc. $<$ http://www.limdep.com/>) was used in this study for the empirical data analysis.

\section{Results and Discussion}

Results for the commercial buyers and consumers surveyed at a garden center are presented in Tables 6 and 7, respectively. The WTP measures in these tables were calculated by taking the ratio between the coefficient of a groundcover attribute and the opposite of the price coefficient (Hu et al., 2005). When interactions were included, the numerator of the WTP measure took the coefficient of both the linear term and the interacted term.

The price variable had a negative and significant coefficient, indicating that when prices were higher, commercial buyers were less likely to purchase any groundcover product. The negative and significant coefficient associated with a variable indicated by

Table 5. Variables for consumer demographic characteristics.

\begin{tabular}{lcrrrl}
\hline Variable & Mean & \multicolumn{1}{c}{ SE } & Minimum & Maximum & Description \\
\hline Male & 0.311 & 0.463 & 0 & 1 & Gender, dummy \\
Age & 47.489 & 14.067 & 21 & 65 & Continuous years \\
Children & 0.656 & 1.013 & 0 & 4 & Number children at home \\
Education & 16.111 & 2.058 & 12 & 18 & Years of education \\
Income & 84,028 & 44,363 & 10,000 & 175,000 & Income before taxes \\
\hline
\end{tabular}

$\mathrm{N}=90$.

"choose neither" in Table 6 suggests that, in general, commercial buyers would not like to give up the opportunity to purchase groundcovers. If they had to lose such opportunities, they would suffer a large loss of utility, represented by the $-\$ 44.40 \mathrm{WTP}$.

All linear terms of groundcover attributes were significant for commercial buyers, except the variable for the flats of Ellepot containers. However, it was found that the size of commercial buyers was an important determinant for their preference and WTP for groundcover attributes. Other variables such as those given in Table 4 were tested but they were not significant factors for commercial buyers' preferences. Specifically, the sales volume of the commercial buyer affected their preference for flats of Ellepot and the plastic containers, because the interaction terms were significant. Generally, flats of Ellepot containers were preferred to SoilWrap containers, which was omitted from the model to avoid the dummy variable trap. When compared with other types of commercial buyers, those with high sales were willing to pay an additional $\$ 11.52$ for flats of Ellepot over the flats of SoilWrap containers, holding all other factors constant.

Commercial buyer preferences for plastic containers were more diverse. Compared with those with medium sales volumes (annual sales between $\$ 250,000$ and $\$ 500,000$ ), buyers with high sales did not prefer flats of plastic containers and their WTP was \$1.55 less compared with that for SoilWrap. Buyers with low sales, on the other hand, preferred plastic containers. Their WTP for plastic containers was $\$ 2.33$ compared with SoilWrap.

Commercial buyers preferred sedum over ajuga for groundcover plants. Holding other factors constant, they were willing to pay $\$ 3.94$ per flat more for sedum. Finally, these buyers preferred 18-count flats over 12-count flats with a negative WTP associated with 12count flats at $\$ 6.99$. Commercial installers prefer to purchase in volume and also appear to place a value on sustainable containers that will reduce installation time.

There are some similarities between the preferences of consumers and commercial buyers but there are also noticeable differences. As data in Table 7 suggest, price had a negative impact on purchasing. Consumers surveyed showed an affinity to purchase groundcover plants because their loss of utility in giving up the opportunity to buy groundcover was measured at $\$ 68.65$. Consumers revealed no clear preference for the flats of plantable containers. This is somewhat contrary to other studies focused on individual plants (Khachatryan et al., 2014a,
Table 6. Choice model estimation result and willingness-to-pay (WTP) measures for commercial buyers.

\begin{tabular}{lccc}
\hline Attribute & Coefficient & SE & WTP \\
\hline Choose neither & $-3.745^{* * *}$ & 0.425 & $-\$ 44.40$ \\
Ellepot & 0.123 & 0.214 & - \\
High sales*Ellepot & $0.849^{* * *}$ & 0.319 & $\$ 11.52$ \\
Plastic & $-1.537^{* * *}$ & 0.308 & - \\
High sales*plastics & $1.406^{* * *}$ & 0.414 & $-\$ 1.55$ \\
Low sales*plastics & $1.750^{* * *}$ & 0.371 & $\$ 2.53$ \\
Sedum & $0.332^{* *}$ & 0.163 & $\$ 3.94$ \\
12-count & $-0.589^{* * *}$ & 0.121 & $-\$ 6.99$ \\
Price & $-0.084 * * *$ & 0.020 & - \\
\hline
\end{tabular}

Adjusted pseudo $R^{2}=0.108$

$* * *$ and ${ }^{* *}$ represent significant at the $1 \%$ and $5 \%$ significance levels, respectively.

Table 7. Choice model estimation result and willingness-to-pay (WTP) measures for consumers surveyed at a garden center near Lexington, $\mathrm{KY}$.

\begin{tabular}{lccc}
\hline Attribute & Coefficient & SE & WTP \\
\hline Choose neither & $-3.098^{* * *}$ & 0.420 & $-\$ 68.65$ \\
Ellepot & 0.037 & 0.148 & $\$ 0.82$ \\
Plastic & $0.981^{* *}$ & 0.434 & - \\
Age*plastic & $-0.025^{* * *}$ & 0.008 & $-\$ 5.04^{z}$ \\
Children*plastic & $-0.344^{* * *}$ & 0.127 & $-\$ 14.13^{y}$ \\
Sedum & $0.219^{*}$ & 0.126 & $\$ 4.86$ \\
12-count & 0.052 & 0.112 & - \\
Children*12-count & $0.186^{* *}$ & 0.093 & $\$ 5.29$ \\
Price & $-0.045^{* * *}$ & 0.010 & - \\
\hline Adju
\end{tabular}

Adjusted pseudo $R^{2}=0.030$.

${ }^{2}$ Based on sample average age of 47.489 years.

${ }^{\mathrm{y}}$ Based on sample median measure: having at least one child at home.

$* * *, * *$, and $*$ represent significant at the $1 \%, 5 \%$, and $10 \%$ significance levels, respectively.

2014b; Yue et al., 2010, 2011); however, the price points in this study for the flats of plants were much higher and could impact consumer WTP for those product attributes. Behe et al. (2013) found that consumer preference for more sustainable containers decreased with increased price. There was heterogeneity among consumers in their preference for flats of plants in plastic containers. Several variables were initially included to explain the heterogeneity, including those variables included in Table 5 and additional information on how much recycling an individual was practicing as a means to conserve. Most of these variables were not significant. The significant variables were included in the result in Table 7. Although flats of plastic containers were generally preferred overall, preference for plastic declined among older buyers and buyers with children at home. Measured at the sample average age, consumers were willing to pay $\$ 5.04$ less for flats of plastic containers than for SoilWrap. For 
households with children, they were willing to pay $\$ 14.13$ less for flats of plastic containers than for SoilWrap.

Although only significant at the $10 \%$ significance level, consumers preferred sedum over ajuga as well. The marginal WTP was $\$ 4.86$. Interestingly, these buyers with children in the household were more in favor of the 12-count flats. They were willing to pay $\$ 5.29$ more for a 12-count flat than for 18 -count flat. They would also be less inclined than the commercial buyers to expect savings through larger volume purchases.

Results from the analysis indicate that cultivators and sellers of flats of groundcover plants should consider the different needs between commercial buyers and consumers. Regardless of purpose, customer heterogeneity should be considered. These factors may be related to the size of a commercial buyer, but reflected to consumers; they suggest demographic characteristics.

Like many other products, groundcover plants are sold with a variety of different attributes. To best design products that fit consumers' need, as shown by this study, one needs to look into the selection of the actual plant as well as the container and the presentation format. This study did not distinguish between the environmental benefits from the biodegradable nature of the containers and the installation time saving as a result of limits in the sample size and survey design. Specific preferences for these attributes could be a point for further evaluation of WTP between buyer groups.

\section{Literature Cited}

Baldwin, I. 2013. National gardening survey: Food gardening earns more than flowers. Today's Garden Center. 8 Dec. 2014. <http://www. todaysgardencenter.com/business-management/ state-of-the-industry/national-gardening-surveyfood-gardening-earns-more-than-flowers $>$.

Behe, B.K., B.L. Campbell, C.R. Hall, H. Khachatryan, J.H. Dennis, and C. Yue.
2013. Consumer preferences for local and sustainable plant production characteristics. HortScience 48:200-208.

Carlsson, F., P. Frykblom, and C.J. Lagerkvist. 2007. Consumer benefits of labels and bans on GM foods - Choice experiments with Swedish consumers. Amer. J. Agr. Econ. 89:152-161.

Colombo, S., J. Calatrava-Requena, and N. Hanley. 2007. Testing choice experiment for benefit transfer with preference heterogeneity. Amer. J. Agr. Econ. 89:135-151.

Dennis, J.H., R.G. Lopez, B.K. Behe, C.R. Hall, C. Yue, and B.L. Campbell. 2010. Sustainable production practices adopted by greenhouse and nursery plant growers. HortScience 45:12321237.

Gladwin, T.N., J.J. Kennelly, and T.S. Krause. 1995. Shifting paradigms for sustainable development: Implications for management theory and research. Acad. Mgt. Rev. 20:874-907.

Hall, C.R., B.L. Campbell, B.K. Behe, C. Yue, R.G. Lopez, and J.H. Dennis. 2010. The appeal of biodegradable packaging to floral consumers. HortScience 45:583-591.

Hall, T.J., J.H. Dennis, R.G. Lopez, and M.K Marshall. 2009. Factors affecting growers' willingness to adopt sustainable floriculture practices. HortScience 44:1346-1351.

Hanemann, M.W. and B. Kanninen. 1999. The statistical analysis of discrete-response CV data, p. 302-441. In: Bateman, I.J. and K.G Willis (eds.). Valuing environmental preferences. Oxford Univ. Press, Oxford, UK.

Hu, W., M.M. Veeman, and W.L. Adamowicz. 2005. Labeling genetically modified food: Heterogeneous consumer preferences and the value of information. Can. J. Agr. Econ. 53:83-102.

Jin, L., M.K. Wohlgenant, and C.D. Safley. 2013. Impact of income and different generation cohorts on nursery products and landscaping project spending. J. Amer. Applied Econ. 45:65-77.

Johnston, R.J. and J.M. Duke. 2007. Willingness to pay for agricultural land preservation and policy process attributes: Does the method matter? Amer. J. Agr. Econ. 89:1098-1115.

Khachatryan, K., B. Campbell, C. Hall, B. Behe, C. Yue, and J. Dennis. 2014a. The effects of individual environmental concerns on willingness to pay for sustainable plant attributes HortScience 49:69-75.
Khachatryan, K., C. Yue, B. Campbell, B. Behe, and C. Hall. 2014b. The effects of individual environmental concerns on willingness to pay for sustainable plant attributes. J. Environ. Hort. 32:64-70.

Klett, J.E. and C.R. Wilson. 2009. Xeriscaping: Ground cover plants. Colorado State Univ. Ext. Fact Sheet No. 7.230

Louviere, J.J., D.A. Hensher, and J.D. Swait. 2000. Stated choice methods: Analysis and applications. Cambridge University Press, Cambridge, UK.

Lusk, J.L., D. Fields, and J. Prevatt. 2008. An incentive compatible conjoint ranking mechanism. Amer. J. Agr. Econ. 90:487-498.

Mason, S.C., T.W. Starman, R.D. Lineberger, and B.K. Behe. 2008. Consumer preferences for price, color harmony and care information of container gardens. HortScience 43:380 384.

McFadden, D. 1974. Conditional logit analysis of qualitative choice behavior, p. 105-142. In: Zarembka, P. (ed.). Frontiers in econometrics. Academic Press, New York, NY.

Nambuthiri, S.S. and D.L. Ingram. 2014. Evaluation of plantable containers for groundcover plant production and their establishment in a landscape. HortTechnology 24:48-52.

Ottman, J.A. 1998. Green marketing: Opportunity for innovation. NTC Business Books, Lincolnwood, IL.

Purser, R.E., C. Par, and A. Montuori. 1995. Limits to anthropocentrism: Toward an ecocentric organization paradigm? Acad. Mgt. Rev. 20:1053-1089.

Rihn, A.L., C. Yue, B. Behe, and C. Hall. 2011. Generations $\mathrm{X}$ and $\mathrm{Y}$ attitudes toward fresh flowers as gifts: Implications for the floral industry. HortScience 46:736-743.

Yue, C.Y., J.H. Dennis, B.K. Behe, C.R. Hall, B. L. Campbell, and R.G. Lopez. 2011. Investigating consumer preference for organic, local, or sustainable plants. HortScience 46:610 615.

Yue, C.Y., C.R. Hall, B.K. Behe, B.L. Campbell, J.H. Dennis, and R.G. Lopez. 2010. Are consumers willing to pay more for biodegradable containers than for plastic ones? Evidence from hypothetical conjoint analysis and nonhypothetical experimental auctions. J. Agr. Applied Econ. 42:757-772. 